Available online at Dakwah: Jurnal Kajian Dakwah dan Kemasyarakatan http://journal.uinjkt.ac.id/index.php/dakwah

Dakwah: Jurnal Kajian Dakwah dan Kemasyarakatan, 24 (2), 2020,158-184

\title{
Peran Penyuluh Agama Dalam Meningkatkan Perilaku Prososial Masyarakat Organik Kebayoran Lama Jakarta Selatan
}

Sahrul Iman sahrulray94@gmail.com Wiraswasta Tinggal di Jakarta

Tasman tasman@uinjkt.ac.id UIN Syarif Hidayatullah Jakarta

\begin{abstract}
The role of religious extension agents is very central in urban life. This study aims to determine the role of instructors in helping urban communities to be more motivated to behave prosocial. The results of this study indicate that the extension agent's efforts to improve the prosocial behavior of the community, among others, are through recitation activities in the Majlis Ta'lim, Training of Body Recollections and Khutoba Training. This activity received a positive response from the community, it was seen that some people were moved to help other communities.
\end{abstract}

Keyword: religious extension agent, pro social, organic society

\begin{abstract}
Abstrak
Peran penyuluh agama sangat sentral dalam kehidupan masyarakat di perkotaan. Penelitian ini bertujuan mengetahui peran penyuluh dalam membantu masyarakat perkotaan untuk semakin tergerak untuk berperilaku prososial. Hasil penelitian ini menunjukkan bahwa upaya penyuluh untuk meningkatkan perilaku prososial masyarakat, di antaranya melalui kegiatan pengajian di Majlis Ta'lim, Pelatihan Pemulasaran Jenazah, dan Pelatihan Khutoba'. Kegiatan tersebut mendapat respon positif dari masyarakat, terlihat sebagian masyarakat tergerak untuk menolong masyarakat lainnya.
\end{abstract}

Kata Kunci: Penyuluh Agama, Pro sosial, Masyarakat organik

Permalink/DOI: http://doi.org/10.15408/dakwah.v24i2.18340

\section{Pendahuluan}

Kota secara ringkas dipahami sebagai wilayah yang mempunyai fungsi sosial yang komplek, terdiri dari berbagai suku bangsa, dan mempunyai tingkat diferensiasi keterampilan penghuninya serta adanya spesialisasi pekerjaan masyarakat yang ada di perkotaan. 
Durkheim melihat kota sebagai kawasan yang mempunyai tingkat diferensiasi pekerjaan yang tinggi dan mempunyai pembagian kerja yang jelas. Dalam konsep solidaritas organik, setiap individu dalam kota mempunyai peranan tersendiri yang tidak bisa digantikan dengan yang lain. Solidaritas organik seperti halnya fungsi organ tubuh manusia yang mempunyai perbedaan dan tingkat ketergantungan yang tinggi satu sama lainnya. Kota merupakan hunian yang relatif besar dengan aktifitas yang beragam secara ekonomi, budaya, agama, pendidikan maupun politik. ${ }^{1}$

Ibnu Khaldun memandang kota merupakan tempat berkembangnya suatu peradaban dan munculnya diferensiasi serta keahlian yang dimiliki penghuninya. Keahlian ini membentuk sebuah pengetahuan dalam membangun peradaban kota. Selain itu kota juga merupakan tempat terjadinya surplus ekonomi. Dengan demikian kota merupakan wilayah yang memiliki peradaban maju dan penduduk yang kaya-raya karena dekat dengan daulah yang merupakan pusat terkumpulnya harta kekayaan rakyat. $^{2}$ Urbanisasi, migrasi, dan komunitas ulang alik merupakan bentuk interaksi yang terjadi hubungan desa kota. Perluasan jalur dan perkembangan bidang transportasi berdampak pada peningkatan intensitas hubungan desa kota. Dari interaksi ini dapat menimbulkan pengaruh positif dan pengaruh negatif bagi desa-kota dan penghuninya. ${ }^{3}$

Perubahan inilah yang menjadi dampak bertambahnya jumlah permasalahan sosial secara signifikan, dan tidak hanya itu namun juga dapat meningkatkan kompleksitas masalah sosial di perkotaan. Akibatnya kota-kota besar tidak hanya menghadapi penurunan moral serta nilai-nilai kemanusiaan tetapi juga peningkatan kerawanan sosial yang mengkhawatirk-an. Selain itu peningkatan jumlah penduduk di pedesaan yang tidak dibarengi dengan penambahan lapangan kerja telah memaksa warga desa untuk berimigrasi ke kota besar khususnya Jakarta. 4

Keberadaan penyuluh agama mengambil peran penting dalam kehidupan bermasyarakat di perkotaan agar kehidupan dapat seimbang dan sejalan dengan apa yang diinginkan oleh semua masyarakat yang beragam, seorang penyuluh agama harus mampu menjadi penyeimbang dan pengayom masyarakat kota agar tetap menjunjung nilai-nilai sosial bermasyarakat, agar masyarakat kota tidak jatuh pada tatanan masyarakat yang apatis dan egois.

Berdasarkan masalah yang muncul di atas dilakukan penelitian, dan untuk mengetahui sejauh mana peran penyuluh agama dalam meningkatkan perilaku prososial masyarakat perkotaan yang dalam konteks ini disebut dengan masyarakat organik di salah satu wilayah DKI Jakarta yakni Kebayoran Lama yang dituangkan bentuk karya ilmiah dengan judul “ Peran Penyuluh Agama Dalam Meningkatkan Perilaku Prososial Masyarakat Organik (Masyarakat Perkotaan) di Kebayoran Lama Jakarta Selatan". 
Penyuluh Agama

Penyuluh agama khususnya islam memiliki peranan penting dalam kehidupan beragama, bermasyarakat, dan bernegara. Berdasarkan keputusan Menteri Agama (KMA) Nomor 79 Tahun 1985 bahwa: Penyuluh agama mempunyai peranan sebagai pembimbing masyarakat, sebagai panutan dan sebagai penyambung tugas pemerintah. ${ }^{5}$

Dalam buku Harun Nasution agama berasal dari kata ad-din, religi (relegere, religare) dan agama dalam bahasa Arab berarti menguasai, menundukkan, patah, balasan dan kebiasaan. Sedangkan dari religi (latin) atau relegere berarti mengumpulkan dan membaca, kemudian religere berarti mengikat. Adapun kata agama terdiri dari dua suku kata " $a$ " berarti "tidak" dan "gam" berarti "pergi" artinya "tidak pergi", tetap ditempat diwarisi turun temurun. ${ }^{6}$

Menurut Hendropuspito, agama adalah suatu jenis sistem sosial yang dibuat oleh penganut-penganutnya yang berproses pada kekuatan-kekuatan non empiris dan didayagunakan untuk mencapai keselamatan bagi mereka dan masyarakat luas pada umumnya. J. Milten Yinger melihat agama sebagai sistem kepercayaan dan praktek di mana suatu masyarakat atau kelompok manusia berjaga-jaga menghadapi masalah terakhir dari hidup. Maksudnya ialah bekal untuk menghadapi hari kiamat dengan mengumpulkan amal kebaikan.7 Dapat diketahui bahwa agama adalah merupakan suatu pegangan hidup yang harus diterapkan dalam kehidupan individu ataupun kelompok. Keduanya mempunyai hubungan saling mempengaruhi dan saling bergantung dengan semua faktor yang ikut membentuk struktur sosial di masyarakat manapun ${ }^{8}$

Penyuluh agama islam memiliki peranan yang cukup strategis di tengahtengah masyarakat, selain ia sebagai pendakwah islam, penyuluh agama islam itu sesuai dengan fungsinya sebagai pembimbing, penerang, dan pembangun masyarakat dengan bahasa agama. Peranan penyuluh agama selain berfungsi sebagai pendorong masyarakat untuk berpartisipasi aktif dalam pembangunan, berperan juga ikut serta mengatasi hambatan yang membangun jalannya pembangunan, khususnya mengatasi dampak negatif. Penyuluh agama sebagai pemuka agama selalu membimbing, mengayomi, dan menggerakkan masyarakat untuk berbuat baik dan menjauhi perbuatan yang terlarang, mengajak kepada sesuatu yang menjadi keperluan masyarakatnya dalam membina wilayahnya baik untuk keperluan sarana kemasyarakatan maupun peribadatan. Penyuluh agama menjadi tempat bertanya dan tempat mengadu bagi masyarakatnya untuk memecahkan dan menyelesaikan dengan nasehatnya. penyuluh agama sebagai pemimpin masyarakat bertindak sebagai imam dalam masalah agama dan masalah kemasyarakatan begitu pula dalam masalah kenegaraan dengan usaha menyukseskan program pemerintah. ${ }^{9}$

\section{Perilaku Prososial}

Perilaku prososial adalah perilaku menolong. Tingkah laku menolong adalah 
tindakan individu yang ditujukan untuk menolong orang lain tanpa adanya keuntungan langsung bagi si penolong. Contoh menolong yang murni adalah altruism, yaitu menolong untuk kesejahteraan orang lain semata (selfless), tanpa motivasi untuk kepentingan diri sendiri (selfish). ${ }^{10}$

Penner, Dividio, Piliavin, dan Schroeder mencatat bahwa istilah prososial mewakili suatu tindakan yang luas yang didefinisikan oleh suatu segmen signifikan masyarakat dan/atau kelompok sosial seseorang sebagai tindakan yang secara umum bermanfaat bagi orang lain. ${ }^{11}$

Tingkah laku menolong, atau dalam psikologi sosial dikenal dengan tingkah laku prososial adalah tindakan individu untuk menolong orang lain tanpa adanya keuntungan langsung bagi si penolong. Deaux, Dane, dan Wrightsman (1993) mengatakan bahwa dalam tingkah laku menolong yang lebih diutamakan adalah kepentingan orang lain dibandingkan kepentingan diri sendiri, terutama dalam situasi darurat. Menolong sebagai tingkah laku yang ditujukan untuk membantu orang lain, dalam beberapa kasus bisa saja tidak dapat mencapai tujuannya, hal ini disebabkan karena penolong tidak mengetahui kesulitan korban yang sesungguhnya atau karena penolong tidak mempunyai keterampilan yang dibutuhkan untuk menolong korban sehingga dapat berakibat fatal, baik bagi penolong maupun yang ditolong. Misalnya, kasus tenggelamnya 5 orang mahasiswa UI di pantai Anyer pada tanggal 13 Juli 2003. Awalnya hanya satu orang yang hanyut dan beberapa orang temannya mencoba untuk menolong. Derasnya arus laut membuat teman temannya yang menolong akhirnya ikut hanyut.

Tingkah laku menolong terjadi dalam kehidupan sehari-hari, bentuknya sangat bervariasi seperti membukakan pintu untuk orang lain yang sedang membawa barang, membantu teman mengambilkan buku di rak, memberi uang pada pengemis, menjadi pendonor darah, ataupun aktif dalam kegiatan sosial. $^{12}$

Menurut Bartal mengartikan bahwa tingkah laku prososial atau tingkah laku yang menimbulkan konsekuensi positif bagi kesejahteraan fisik maupun psikis orang lain. Tingkah laku ini dilakukan secara sukarela (voluntary) dan menguntungkan (benefit) orang lain tanpa antisipasi (reward) eksternal, yang meliputi menolong (helping), membantu (aiding), membagi (sharing), dan menyumbang (donating). Lebih jelas lagi, pengertian prilaku prososial mencakup tindakantindakan sharing (membagi), cooperative (kerjasama), donating (menyumbang), helping (menolong), honesty (kejujuran), generosity (kedermawanan), serta mempertimbangkan hak dan kesejahteraan orang lain. ${ }^{13}$

\section{Kota dan Masyarakat Organik}

Menurut Sujarto (1970), kota merupakan kesatuan masyarakat yang heterogen dan masyarakat kota mempunyai tingkat tuntutan kebutuhan yang lebih banyak apabila dibandingkan dengan penduduk pedesaan. Menurut 
Bintarto (1977), kota adalah sebuah bentang budaya yang ditimbulkan oleh unsur-unsur alami dan non-alami dengan gejala pemusatan penduduk yang cukup besar dan corak kehidupan yang bersifat heterogen dan materialistis dibandingkan dengan daerah belakangnya. Tinjauan lebih rinci dikemukakan oleh Amiruddin (1970) dalam Pedoman Perencanaan Lingkungan Perumahan Untuk Kota-kota di Indonesia yang mengemukakan bahwa sesuatu tempat sebagai kota apabila memiliki ciri-ciri yakni: Ukurannya relatif besar; Permanen; Padat; Hubungan sosialnya heterogen; ${ }^{14}$

Determinist Theory atau dikenal juga dengan theory of urban anomie. Writh (1938) sebagai salah satu tokoh yang paling berpengaruh dalam teori ini memulai analisanya dengan mendefinisikan kota sebagai sebuah wilayah yang relatif besar, padat, dan tempat tinggal permanen dari individu yang secara sosial sangat beragam. Writh menganalisis bagaimana urbanisasi menghasilkan disorganisasi sosial dan gangguan kepribadian. Argumen tersebut didasarkan pada pemikiran George Simmel. Simmel memusatkan perhatiaannya pada cara hidup di kota yang mengubah cara berfikir dan kepribadian individu. Bagaimana stimulasi yang cepat dan terputus dirubah oleh stimulasi yang datang dari dalam dan luar individu. Stimulasi yang paling berpengaruh menurut Simmel adalah pemandangan, suara, bau, tindakan orang lain, sehingga individu merespon untuk melindungi diri dan beradaptasi dengan pikiran dan hati. Dengan adanya stimulasi dan cara individu merespon tersebut menjadikan individu lebih intelek, rasional, dan berjarak secara emosional dengan orang lain. Suara klakson, telepon, pantulan cahaya, pandangan dan prilaku orang asing, berita surat kabar mempengaruhi prilaku individu dengan reaksi yang berbeda-beda. Hal ini sangat memungkinkan bagi individu untuk mengalami gangguan kepribadian.

Analisa struktur sosial dalam teori ini tidak jauh berbeda dengan argument psikologi, tetapi dalam proses yang berbeda. Dalam kompetisi ekonomi, spesialisasi pekerjaan, meraih keunggulan, dan kemajemukan kota menghasilkan keberagaman aktivitas kehidupan sosial, seperti di dunia pekerjaan, kehidupan bertetangga, rumah tangga, dan sebagainya. Sehingga waktu dan perhatian individu terpecah dan terputus pada tempat dan orang yang berbeda. Keberagaman aktivitas ini membuat individu terisolasi dari kehidupan sosialnya dan inilah yang memberi peluang terjadinya anomi karena hilangnya ikatan-ikatan sosial yang berisi nilai-nilai. ${ }^{15}$

Untuk mengkategorikan bahwa masyarakat Kebayoran Lama dapat dikategorikan sebagai masyarakat organik, maka kita bisa melihat perbandingan yang dikemukakan oleh Nelson tentang perbedaan kota dan bukan kota:

\begin{tabular}{|l|l|l|l|}
\hline No & $\begin{array}{l}\text { Untuk } \\
\text { Pembeda }\end{array}$ & Desa & Kota \\
\hline 1. & $\begin{array}{l}\text { Mata } \\
\text { Pencaharian }\end{array}$ & $\begin{array}{l}\text { Agraris } \\
\text { Homogen }\end{array}$ & $\begin{array}{l}\text { Non } \\
\text { Agraris } \\
\text { Heterogen }\end{array}$ \\
\hline 2. & Ruang Kerja & Terbuka/L & Ruang \\
\hline
\end{tabular}




\begin{tabular}{|c|c|c|c|}
\hline & & apangan & Tertutup \\
\hline 3. & $\begin{array}{l}\text { Musim/Cua } \\
\text { ca }\end{array}$ & $\begin{array}{l}\text { Penting/M } \\
\text { enentukan }\end{array}$ & $\begin{array}{l}\text { Tidak } \\
\text { Penting }\end{array}$ \\
\hline 4. & $\begin{array}{l}\text { Keahlian/Ke } \\
\text { terampilan }\end{array}$ & $\begin{array}{l}\text { Umum/Me } \\
\text { nyebar }\end{array}$ & $\begin{array}{l}\text { Spesialisa } \\
\text { si dan } \\
\text { Mengelom } \\
\text { pok }\end{array}$ \\
\hline 5. & $\begin{array}{l}\text { Jarak } \\
\text { Rumah } \\
\text { dengan } \\
\text { tempat kerja }\end{array}$ & $\begin{array}{l}\text { Dekat } \\
\text { (relatif) }\end{array}$ & $\begin{array}{l}\text { Jauh } \\
\text { (terpisah) } \\
\text { relative }\end{array}$ \\
\hline 6. & $\begin{array}{l}\text { Kepadatan } \\
\text { Penduduk }\end{array}$ & Rendah & Tinggi \\
\hline 7 . & $\begin{array}{l}\text { Kepadatan } \\
\text { Rumah }\end{array}$ & Rendah & Tinggi \\
\hline 8. & $\begin{array}{l}\text { Kontak } \\
\text { Sosial }\end{array}$ & $\begin{array}{l}\text { Frequensi } \\
\text { Rendah }\end{array}$ & $\begin{array}{l}\text { Frequensi } \\
\text { Tinggi }\end{array}$ \\
\hline 9. & Strata Sosial & Sederhana & Kompleks \\
\hline 10. & $\begin{array}{l}\text { Kelembagaa } \\
\mathrm{n}\end{array}$ & Terbatas & Kompleks \\
\hline 11. & $\begin{array}{l}\text { Kontrol } \\
\text { Sosial }\end{array}$ & $\begin{array}{l}\text { Adat/Tradi } \\
\text { si }\end{array}$ & $\begin{array}{l}\text { UU } \\
\text { Tertulis } \\
\text { berperan }\end{array}$ \\
\hline 12. & $\begin{array}{l}\text { Sifat } \\
\text { Masyarakat }\end{array}$ & $\begin{array}{l}\text { Gotong } \\
\text { Royong }\end{array}$ & $\begin{array}{l}\text { Patembay } \\
\text { an }\end{array}$ \\
\hline 13. & $\begin{array}{l}\text { Mobilitas } \\
\text { Penduduk }\end{array}$ & Rendah & Tinggi \\
\hline 14. & $\begin{array}{l}\text { Status } \\
\text { Sosial }\end{array}$ & Stabil & $\begin{array}{l}\text { Tidak } \\
\text { Stabil }^{16}\end{array}$ \\
\hline
\end{tabular}

\begin{tabular}{|c|c|c|}
\hline & Opinion & $\begin{array}{l}\text { labor causes } \\
\text { individuality }\end{array}$ \\
\hline $\begin{array}{c}\text { Laws, } \\
\text { Morals, } \\
\text { Sosial, } \\
\text { Controls }\end{array}$ & $\begin{array}{l}\text { Repressive } \\
\text { Punishment }\end{array}$ & $\begin{array}{l}\text { Emphasis on } \\
\text { restitutive law }\end{array}$ \\
\hline $\begin{array}{l}\text { Political } \\
\text { structur }\end{array}$ & $\begin{array}{c}\text { Public } \\
\text { meeting }\end{array}$ & $\begin{array}{c}\text { Contractual } \\
\text { relationship of } \\
\text { government to } \\
\text { people }\end{array}$ \\
\hline Economic & $\begin{array}{l}\text { Sharing- } \\
\text { communal } \\
\text { property }\end{array}$ & $\begin{array}{c}\text { Contractual and } \\
\text { Private } \\
\text { Property }\end{array}$ \\
\hline Religion & $\begin{array}{l}\text { Totemic- } \\
\text { Tribal and } \\
\text { Local } \\
\text { patriotism }\end{array}$ & $\begin{array}{c}\text { Individualizatio } \\
n \text { of God- } \\
\text { monotoism and } \\
\text { polytheism }\end{array}$ \\
\hline Suicide & Altruistic & $\begin{array}{l}\text { Egoistic and } \\
\text { anomic }^{17}\end{array}$ \\
\hline
\end{tabular}

Penemuan di lapangan oleh penulis menunjukkan masyarakat Kebayoran Lama tersebut sudah masuk dalam kategori yang dikemukakan Durkheim, karena prilaku masyarakat Kebayoran Lama tidak lagi di dominasi oleh tradisi, kepercayaan, dan opini, tetapi sudah mengarah ranah rasional dan individual. Dilihat dari hukum yang Untuk memperjelas bahwa masyarakat Kebayoran Lama sudah layak disebut sebagai masyarakat organik seperti yang dikemukakan oleh teori Durkheim dapat dilihat pada tipologi masyarakat menurut Durkheim, kemudian dibandingkan dengan masyarakat Kebayoran Lama.

\begin{tabular}{|c|c|c|}
\hline Factor & Mechanical & Organic \\
\hline Behavior & $\begin{array}{c}\text { Dominated } \\
\text { by tradition, } \\
\text { Beliefs, }\end{array}$ & $\begin{array}{c}\text { Increasindividu } \\
\text { ality } \\
\text { specialization of }\end{array}$ \\
\hline
\end{tabular}
dipakai di Kebayoran Lama, tidak lagi memakai hukuman yang didasarkan tradisi atau adat, tetapi sudah memakai hukum berdasarkan undang-undang atau aturan pemerintah. Dilihat dari sudut pandang politik, masyarakat Kebayoran Lama hanya sedikit yang memakai musyawarah dengan pemangku adat atau agama, tetapi lebih mengedepankan hubungan mediasi dengan pemerintah di tengah-tengah masyarakat. Dari segi ekonomi, masyarakat Kebayoran Lama tidak lagi memakai sistem berbagi atau 
barter tetapi sudah mengarah kepada pemakaian uang dalam segala hal. Dari cara beragama masyarakat Kebayoran Lama tidak lagi menganut agama lokal atau mengakui banyak Tuhan, tetapi sudah mengakui adanya satu Tuhan. Dilihat dari sikap melihat orang lain dalam kasus bunuh diri, kalau di desa di dasarkan pada sifat menolong tanpa pamrih, kalau di Kebayoran Lama sudah mulai egois dan rusak karena kewaspadaan.

Tetapi pada intinya Masyarakat Kebayoran Lama bisa dikategorikan dengan masyarakat organik karena sebagian masyarakatnya, sudah mulai individual dan rasional. Selain itu, masyarakat Kebayoran Lama juga memiliki pekerjaan yang berbeda-beda dan didasarkan pada hubungan fungsional atau materi dan profesi, serta adanya differensiasi sosial diantara masyarakatnya dan pembagian kerja yang jelas yang menggambarkan ciri-ciri masyarakat organik dalam teori Durkheim.

\section{GAMBARAN UMUM KECAMATAN KEBAYORAN LAMA DAN KANTOR URUSAN AGAMA (KUA) KEBAYORAN LAMA}

\section{Profil Kecamatan Kebayoran Lama}

1. Sejarah

Nama Kebayoran berasal dari bahasa Betawi "kabayuran" yang artinya tempat penimbunan kayu bayur (pterospermum javanicum). Kayu bayur tersebut dianggap sangat baik karena kuat dan tahan terhadap serangan rayap.

Wilayah Kebayoran Lama membentang dari pertigaan Rawa Belong, Kemandoran, Palmerah hingga di selatan yakni Pasar Jumat, Ciputat, dan Lebak Bulus. Wilayah ini terdapat sejumlah Mall mulai dari ITC Permata Hijau, hingga Pondok Indah Mall. Wilayah yang masih rindang terutama di sepanjang

\begin{tabular}{|c|c|c|c|c|c|c|c|c|}
\hline & \multicolumn{8}{|c|}{$\begin{array}{c}\text { Tabel Perkembangan Jumlah Mobilitas Penduduk } \\
\text { Tahun } 2016\end{array}$} \\
\hline \multirow[b]{2}{*}{ No } & \multirow[b]{2}{*}{ Kelurahan } & \multicolumn{7}{|c|}{ Keadaan Penduduk Jumlah Jiwa } \\
\hline & & Lahir & Datang & Mati & Pindah & $\begin{array}{l}\text { Lahir \& } \\
\text { Datang }\end{array}$ & $\begin{array}{l}\text { Mati \& } \\
\text { Pindah }\end{array}$ & KET \\
\hline 1. & Grogol Utara & 124 & 271 & 39 & 286 & 395 & 325 & \\
\hline 2. & Grogol Selatan & 186 & 302 & 42 & 202 & 488 & 244 & \\
\hline 3 . & Cipulir & 141 & 185 & 39 & 199 & 326 & 238 & \\
\hline 4. & Keb. Lama Utara & 128 & 206 & 45 & 287 & 334 & 332 & \\
\hline 5. & Pondok Pinang & 176 & 225 & 42 & 247 & 401 & 289 & \\
\hline 6. & Keb. Lama Selatan & 130 & 284 & 51 & 298 & 414 & 349 & \\
\hline & JUMLAH & 885 & 1.473 & 258 & 1.519 & 2.358 & 1.777 & \\
\hline
\end{tabular}


jalan raya Kebayoran Lama menjadikan tempat ini cukup asri dan masih hijau guna menyegarkan mata.

\section{Ekonomi}

Wilayah Kebayoran Lama terletak sangat strategis di pusat kota berbatasan dengan Provinsi Banten, sehingga menjadikan wilayah Kecamatan Kebayoran Lama menarik bagi penduduk untuk pemukiman baik bagi mereka yang berprofesi sebagai karyawan pegawai perkantoran, maupun pedagang.

Apabila ditinjau dari segi kehidupan sehari-hari penduduk Kecamatan Kebayoran Lama mempunyai kegiatan kerja sebagai berikut :

\begin{tabular}{|c|c|}
\hline Masyarakat & Jumlah Jiwa \\
\hline Pegawai Negeri & 6.212 Jiwa \\
\hline$\overline{\mathrm{ABRI}}$ & 2.786 Jiwa \\
\hline Swasta & 85.822 Jiwa \\
\hline Industri/Buruh & 31.355 Jiwa \\
\hline Lain-lain & 174.428 Jiwa \\
\hline JUMLAH & 300.603 \\
\hline
\end{tabular}

3. Agama

Masyarakat

Kecamatan

Kebayoran Lama merupakan masyarakat yang manganut agama yang beragam berdasarkan apa yang dipercayai oleh masing-masing individu. Dalam persentasi keagamaan wilayah Kecamatan Kebayoran Lama memeluk enam agama sebagai berikut :

\begin{tabular}{|c|c|}
\hline Agama & Jumlah Jiwa \\
\hline Islam & 259.730 Jiwa \\
\hline Kristen & 22.403 Jiwa \\
\hline Khatolik & 13.673 Jiwa \\
\hline Budha & 4.300 Jiwa \\
\hline
\end{tabular}

\begin{tabular}{|c|c|}
\hline Hindu & 497 jiwa \\
\hline JUMLAH & $\mathbf{3 0 0 . 6 0 3}$ Jiwa $^{\mathbf{1 8}}$ \\
\hline
\end{tabular}

Kecamatan Kebayoran Lama merupakan daerah yang memiliki banyak pengajian dan kegiatan agama islam yang diselenggarakan di berbagai Majlis Ta'lim yang tersebar di seluruh wilayah Kebayoran Lama. Secara Keseluruhan di kecamatan Kebayoran Lama terdapat 846 Rukun Tetanggga (RT) dan 77 Rukun Warga (RW) dan hampir setengah dari seluruh RT di Kebayoran Lama memiliki Majlis Ta'lim yang berjumlah 393 Majlis Ta'lim di seluruh wilayah Kebayoran Lama. Kebayoran Lama Memiliki 73 Taman Pendidikan Al Qur'an (TPQ) adalah lembaga atau kelompok masyarakat yang menyelenggarakan pendidikan nonformal jenis keagamaan Islam yang bertujuan untuk memberikan pengajaran membaca Al Qur'an sejak usia dini, serta memahami dasar-dasar agama Islam pada anak usia taman kanak-kanak dan sekolah dasar. Rumah ibadah umat islam atau yang sering disebut Masjid dan Mushalla terdapat sebanyak 84 Unit Masjid dan 141 Unit Mushalla di seluruh kecamatan Kebayoran Lama. Ustadz atau Ustadzah adalah sebutan bagi guru umat islam yang mengajarkan ilmu agama atau orang yang dapat dijadikan panutan masyarakat dalam bidang agama Islam. Di seluruh wilayah Kebayoran terdapat 62 Ustadz dan 12 Ustadzah yang aktif mengajarkan agama Islam yang dilaksanakan di Masjid, Musholla, dan Majlis Ta'lim yang tersebar di seluruh daerah kecamatan Kebayoran Lama. Selain Ustadz dan Ustadzah terdapat juga 22 Qori' dan 26 Qori'ah di seluruh 
wilayah kecamatan Kebayoran Lama. Secara umum kecamatan Kebayoran Lama menganut banyak organisasi keagamaan dan yang paling dominan terdapat sebanyak 8 organisasi keagamaan yang di anut oleh umat islam di Kebayoran Lama. Diantaranya Nahdhotul Ulama (NU) merupakan organisasi keagamaan yang di anut oleh mayoritas umat Islam di Kebayoran Lama dan tersebar di seluruh kelurahan. Fenomena tersebut tidak terlepas dari banyaknya Ustadz dan Kiai yang menyebarkan ajaran islam yang menganut pemahaman Ahlussunnah Waljama'ah sebagai contoh salah satunya Kiai H. Zainuddin MZ dahulu beliau aktif berdakwah di daerah Kebayoran Lama. ${ }^{19}$

Muhammadiyah merupakan organisasi keagamaan kelas dua di daerah Kebayoran Lama, meskipun menyebar di seluruh kelurahan tetapi keberadaannya lebih sedikit dibanding dengan NU karena hanya sebagian kecil masyarakat yang menganut organisasi tersebut karena pengaruh dari Kiai H. Zainuddin MZ pada masa hidupnya di Kebayoran Lama, dan terbukti dengan Masjid atau Mushalla yang memiliki nama At Taqwa yang identik dengan nama tempat ibadah kelompok Muhammadiyah tidak begitu banyak di jumpai di kecamatan Kebayoran Lama. ${ }^{20}$

LDII ( Lembaga Dakwah Islam Indonesia) merupakan organisasi keagamaan kelas tiga di kebayoran Lama karena penganut organisasi ini tidak di temukan di seluruh wilayah Kebayoran Lama, penganut organisasi keagamaan ini hanya ditemukan di tiga kelurahan yaitu, Kebayoran Lama Selatan,
Kebayoran Lama Utara, dan Grogol Selatan.

Qodariah Naqsabandiyah, Majelis Dzikir, Majlis Tabligh, Jamaah Tabligh dan Ahmadiyah merupakan organisasi minoritas di daerah kecamatan Kebayoran Lama karena hanya di temukan dalam masing-masing satu kelurahan berbeda dan jumlah pengikutnya tidak banyak. Qadariyah Naqsabandiyah hanya ditemukan di kelurahan Pondok Pinang, Majlis Dzikir di kelurahan Grogol Utara, Majlis Tabligh di kelurahan Kebayoran Lama Utara, Jamaah Tabligh di kelurahan Grogol Selatan, dan Ahmadiyah terdapat di kelurahan Kebayoran Lama Selatan.

Dapat di simpulkan bahwa masyarakat Kebayoran Lama merupakan masyarakat yang tingkat keagamaannya tinggi, karena dapat dilihat dari sarana keagamaan seperti Majlis Ta'lim, Masjid, TPQ, Mushalla sangat banyak di temukan di kecamtan Kebayoran Lama. Selain itu keadaan beragama masyarakat dapat disebut masyarakat yang taat beragama khususnya agama islam dilihat dari banyaknya kegiatan keagamaan di majlis Ta'lim, Masjid, Mushalla dan lain sebagainya. Begitu juga jika dilihat dari banyaknya Ustadz dan Ustadzah, Qori' dan Qori'ah, Hafidz dan Hafidzah serta kesenian Islam seperti Qashidah, Marawis, dan Gambus, lembaga islam yang mengurusi Anak Yatim dan terakhir organisasi keagamaan Islam semuanya menunjukkan bahwa masyarakat Kebayoran Lama merupakan masyarakat yang taat beragama Islam. 
Pelaksanaan Penyuluhan yang Bertujuan Meningkatkan Prososial Masyarakat Organik Kebayoran

Lama

Jumlah penyuluh agama fungsional di kecamatan Kebayoran Lama sebanyak enam orang, lima diantaranya perempuan dan satu laki-laki. Yaitu, Ustadz Komarudin, Ustadzah Siti Pahriyah, Ustadzah Mumun Fauziah, Ustadzah Rodhotul Janah, Ustadzah Khalidah, Ustadzah Zudaedah. Dari wawancara yang penulis lakukan terhadap coordinator penyuluh ustadz Komarudin mengatakan bahwa penyuluh agama Kebayoran Lama mengikuti aturan dari Kemeterian Agama RI dalam segi tugas pokok dan fungsi, dalam pelaksanaannya penyuluh memakai ideologi yang mereka bawa masingmasing yakni Ahlussunnah Wal Jama'ah dengan pemahaman organisasi Nahdhlatul Ulama. Tipe pemikiran penyuluh KUA Kebayoran Lama juga tipe penyuluh yang menyesuaikan pesan agama dengan Negara artinya mensinkronkan agama dengan negara tidak berpemahaman liberal, atau radikal.

Melalui penuturan koordinator penyuluh Kebayoran Lama Ustadz Komarudin bahwasanya untuk mengadakan kegiatan yang berbasis masyarakat yang bertujuan memperbaiki masyarakat, penyuluh agama berangkat dari kegiatan Kantor Urusan Agama tentang pembinaan umat melalui penyuluhan Majlis Ta'lim, Masjid, Musholla dan Lain-lain. Lebih jelas beliau memaparkan bahwa penyuluhan yang berbasis

kegiatan-kegiatan kemasyarakatan masuk melalui jalur kegiatan KUA tersebut. ${ }^{21}$

Sejalan dengan penuturan Ustadz Komarudin maka penulis juga berangkat dari kegiatan pembinaan umat melalui penyuluhan di Majlis Ta'lim, Mesjid, Musholla dalam merumuskan peran penyuluh agama dalam meningkatkan prososial masyarakat organik kebayoran lama. Tentunya, karena dalam konteks penyuluh agama adalah orang yang memberikan informasi melalui bahasa agama maka dapat dipahami bahwa pelaksanaan kegiatan-kegiatan yang bertujuan untuk meningkatkan prososial masyarakat Kebayoran Lama tentu tidak terlepas dari apa yang disebut bahasa agama dan kegiatan keagamaan. Oleh karena itu, pelaksanaan kegiatan tersebut meskipun penyampaiannya dengan bahasa agama tetapi juga berefek kepada kehidupan sosial bermasyarakat, karena agama dapat berfungsi sebagai etos pembangunan. Maksudnya, bahwa agama yang menjadi panutan seseorang atau masyarakat jika diyakini dan dihayati secara mendalam mampu memberikan suatu tatanan nilai moral dan sikap, selanjutnya nilai moral tersebut akan memberikan garis-garis pedoman tingkah laku seseorang dalam bertindak sesuai dengan ajaran agamanya. ${ }^{22}$

Dari wawancara yang penulis lakukan dengan berbagai informan tentang keadaan wilayah Kebayoran Lama apakah sudah layak disebut kota atau tidak, dan apakah masyarakat Kebayoran Lama termasuk dalam kategori masyarakat yang peduli,

"Bisa jadi iya bisa jadi engga, kenapa demikian karena masih banyak juga 
tradisi yang mirip dengan masyarakat di desa, meskipun sudah tidak banyak lagi, Di satu sisi ada yang begitu di sisi lain ada juga yang masih kaya orang di desa masih bersatu, gotong royong, itu yang saya lihat sih ya di kelurahan sini." ${ }_{33}$

Berdasarkan wawancara tersebut penulis dapat menyimpulkan bahwa pendapat masyarakat dan penyuluh berbeda menanggapi keadaan Kebayoran Lama, di satu sisi memang layak disebut kota karena dekat dengan pusat kota dan banyaknya infrastruktur yang menunjang daerah tersebut layak disebut kota. Di sisi lain, bisa juga disebut mirip desa karena keadaan masyarakatnya sebagian masih peduli terhadap sesama manusia dan masih bersatu dan guyub. Tetapi pada intinya Kebayoran Lama sudah termasuk ke dalam kota apabila di lihat dari klasifikasi yang diberikan oleh Durkheim pada bab II. Dari segi administratif dan sistem pemerintahan sudah layak disebut sebagai kota berdasarkan daerah teritorial yang berlaku sebagai daerah Khusus Ibukota Jakarta. Pernyataan tersebut di dukung dengan teori Ibnu Khaldun yang melihat kota merupakan wilayah yang memiliki peradaban maju dan penduduk yang kaya-raya karena dekat dengan daulah yang merupakan pusat terkumpulnya harta kekayaan rakyat. Dari hasil pengamatan penulis terhadap masyarakat Kebayoran Lama yang memang sebagian sudah masuk ranah berfikir rasional dan individual, pernyataan tersebut penulis ungkapkan karena penulis sudah tinggal selama 4 tahun di daerah Kebayoran Lama.
Berdasarkan wawancara dan observasi yang penulis lakukan di KUA Kebayoran Lama terdapat beberapa kegiatan penyuluhan yang bertujuan untuk meningkatkan kualitas keberagamaan dan berpotensi meningkatkan prososial masyarakat Kebayoran Lama.

Dari observasi penulis terdapat delapan kegiatan yang berpotensi meningkatkan prososial seperti yang diucapkan oleh Ustadzah Pahriyah mulai dari Pengajian di Majlis Ta'lim, Pengajian Assakinah, Pelatihan Master of Ceremony, Pelatihan Pemulasaran Jenazah, Pelatihan Khutoba', Santunan Anak Yatim, Konseling, dan Ngaji Kitab. Tetapi menurut penulis yang paling berpotensi meningkatkan prososial ada tiga kegiatan, yaitu :

1. Pengajian Agama di Majlis Ta'lim, KUA, Masjid, Dll.

Majlis Ta'lim merupakan tempat pengajian bagi orang-orang yang ingin mendalami ajaran-ajaran agama islam sebagai sarana dakwah dan pengajaran agama, biasanya diikuti oleh kaum ibu, bapak-bapak, dan remaja tergantung jadwal yang diberikan bagi masingmasing kelompok tersebut. Pengajian di Majlis Ta'lim adalah salah satu bentuk kepedulian penyuluh terhadap masyarakat agar masyarakat memiliki pengetahuan agama yang lebih baik, penyuluh mengambil peran sebagai pemberi informasi dan edukasi bagi masyarakat dalam hal ilmu agama dan hubungan sosial bermasyarakat, melalui materi-materi yang sifatnya berhubungan dengan kehidupan bersama dengan bahasa agama. Majlis Ta'lim merupakan 
sarana bagi penyuluh untuk memberikan dakwah dan wejangan-wejangan kepada masyarakat yang berhubungan dengan perkara yang sifanya peningkatan kualitas keberagamaan dan peningkatan kualitas sosial bermasyarakat.

Dari penjelasan penyuluh penulis mendapatkan informasi bahwa kegiatan Majlis Ta'lim ini rutin di gelar hampir setiap hari dan dilaksanakan di tempat yang berbeda-beda dengan melihat kondisi jama'ahnya, terkadang dilakukan di Mesjid, Mushola, dan instansi pemerintahan seperti di Kantor Kelurahan dan Kecamatan. Masingmasing Majlis Ta'lim dikunjungi satu kali dalam seminggu, waktunya tidak pasti karena kadang dilaksanakan pada pagi hari dan lebih sering dilakukan pada siang hari setelah zuhur. Masing-masing penyuluh memiliki sedikitnya 6 binaan Majlis Ta'lim di wilayah yang sudah ditentukan. Pesertanya terdiri dari bapak-bapak, ibu-ibu, dan remaja, tetapi pada umumnya lebih banyak di dominasi oleh ibu-ibu PKK dengan jumlah sekitar 20-50 orang saja, dan terkadang kurang dari 20 orang, tergantung kesibukannya masing-masing ketika diadakan pengajian di Majlis Ta'lim.

Di dalam pengajian Majlis Ta'lim penyuluh menyampaikan materi yang berkaitan dengan ilmu-ilmu agama dan ilmu-ilmu sosial bermasyarakat yang di ajarkan melalui akhlak. Ilmu agama yang dibahas antara lain Ilmu Tauhid berkaitan dengan keyakinan terhadap sang pencipta dan hal yang gaib yang harus diyakini keberadaannya, seperti Malaikat, Surga, Neraka, Akhirat, dan makhluk Allah yang lain yang tidak bisa dilihat oleh mata, serta kewajiban mengimani Rasul-rasul, Kitab-kitab, Hari Qiyamat, dan Qodar Baik dan Qodar Buruk. Ilmu Fiqih juga diterangkan dalam pengajian di Majlis Ta'lim seperti pembahasan thoharoh (bersuci), shalat, puasa, zakat, dan haji. Selain itu penyuluh juga membahas makanan yang halal dan haram dalam islam, nikah, hukum pidana, hukum harta warisan, dan hukum jual beli yang sesuai dengan ajaran islam. Ilmu Akhlak berkaitan dengan tata cara bermasyarakat, materi yang disampaikan berkaitan dengan kepedulian sesama manusia diantaranya yang berhubungan dengan hubungan manusia dengan manusia lain seperti jujur, ikhlas, amanah, tawadhu', sabar, pemaaf, penolong, rajin, disiplin, bermanfaat, cerdas, cinta damai, tanggung jawab, sabar, persaudaraan, peduli sosial, dan berbagi.

Pengajian di Majlis ta'lim adalah salah satu bentuk kepedulian penyuluh terhadap masyarakat agar masyarakat memiliki pengetahuan agama yang lebih baik, penyuluh berusaha mengumpulkan masyarakat agar terjalin interaksi dalam masyarakat, sebab jika sering terjadi interaksi dalam masyarakat akan dapat menumbuhkan sikap positif dalam masyarakat seperti tolong-menolong, toleran, harmonis, gotong-royong dan sebagainya.

Dari wawancara penulis di atas menanggapi konten ceramah yang berkaitan dengan prososial terhadap informan, dapat diketahui bahwa mereka sangat senang dengan materi yang disampaikan oleh Kiai $H$. Syarifuddin Amsi, selain itu mereka juga sangat 
menikmati isi ceramahnya karena berhubungan dengan kehidupan seharihari mereka sebagai masyarakat yang tinggal di perkotaan yang membutuhkan formula-formula untuk menghilangkan sifat individualis yang sedang menggerogoti masyarakat perkotaan. Informan, sebagai perwakilan masyarakat Kebayoran Lama juga terlihat ingin mengamalkan apa yang sudah disampaikan penceramah meskipun dimulai dari hal-hal yang kecil terlebih dahulu seperti membantu orang yang tersasar dengan menunjukkan arah jalan.

Dari beberapa informan yang penulis wawancarai dapat disimpulkan bahwa materi-materi akhlak yang berkaitan dengan kehidupan bermasyarakat seperti berlomba-lomba dalam kebaikan dan berbuat baik terhadap sesama manusia, dapat meningkatkan prososial masyarakat perkotaan. Seperti diutarakan oleh ibu Amanih dan ibu Muntamah yang memang sudah mulai mengamalkan apa yang disampaikan oleh penceramah dalam kehidupan nyata. Karena semakin masyarakat mengetahui nilai-nilai prososial dalam bahasa agama, maka masyarakat semakin ingin untuk melaksanakannya selanjutnya prososial masyarakat akan semakin tinggi dan peka terhadap lingkungan sekitar mereka tinggal. Karena sesungguhnya prososial adalah sifat simpati terhadap orang lain kemudian dibarengi dengan tindakan untuk menyempurnakan simpati tersebut.

2. Pelatihan Pemulasaran Jenazah Pelatihan yang di laksanakan di KUA Kebayoran Lama pada tanggal 24 Oktober 2017 di Aula KUA Kebayoran
Lama lantai 2, di hadiri oleh 24 peserta perempuan dari enam kelurahan yang tersebar di Kebayoran Lama. diantaranya 5 orang dari Pondok Pinang, 3 orang dari Kebayoran Lama Selatan, 4 orang dari Kebayoran Lama Utara, 2 orang dari Cipulir, 8 orang dari Grogol Selatan dan 2 orang dari Grogol Utara. Pada pelatihan ini Ustadz Abdurrahman dari Kebayoran Lama Selatan menjadi narasumber, dibantu oleh ustadzah Pahriyah sebagai moderator.

Penyuluh agama membuat pelatihan pemulasaran jenazah berdasarkan keinginan penyuluh agar masyarakat Kebayoran Lama bisa melakukan pemulasaran jenazah bagi orang yang meninggal di daerah tempat mereka masing-masing. Pelatihan pemulasaran jenazah merupakan tata cara mengurusi jenazah yang sudah meninggal dunia, atau kewajiban bagi orang yang berada di sekitar tempat orang yang meninggal tersebut untuk melaksanakan empat hal kepada seorang jenazah yang sudah meninggal dunia. Pelatihan pemulasaran jenazah ini dimulai dengan memandikan jenazah, kemudian mengkafani, mensholatkan dan terakhir dikebumikan atau dikuburkan.

Penyuluh agama Kebayoran Lama berharap mereka yang hadir meskipun tidak bisa, tetapi setidaknya mengetahui apa saja hal yang harus dilakukan bagi orang yang sudah meninggal, agar masyarakat bisa melakukannya dan tidak perlu lagi susah-susah untuk mencari orang yang bisa melaksanakan fardu kifayah yang empat bagi orang yang meninggal. 
Pelatihan pemulasaran jenazah memiliki nilai prososial karena pelatihan pemulasan jenazah sangat dibutuhkan masyarakat, semua manusia akan mengalami yang namanya meninggal. Kalau misalnya masyarakat sekeliling orang yang meninggal tidak ada yang bisa mengurus jenazah sesuai dengan anjuran agama islam tentu akan menimbulkan masalah bagi masyarakat, maka penyuluh mengambil peran penting dalam membina masyarakat agar bisa mengurus jenazah orang yang meninggal jika sewaktu-waktu di daerah tersebut tidak ada yang bisa mengurus jenazah. Penyuluh berusaha mengajak masyarakat agar bersedia hadir di KUA mengikuti pelatihan, kemudian memberikan pelatihan agar masyarakat memahami tata cara mengurus jenazah.

Untuk melihat efek dari pelatihan pemulasaran jenazah terhadap masyarakat, penulis melakukan wawancara dengan beberapa informan. Berdasarkan wawancara penulis kepada ibu Emma beliau menuturkan bahwa pelatihan ini sangat bermanfaat bagi masyarakat karena sangat banyak masyarakat yang tidak bisa untuk mengurusi jenazah, dengan adanya pelatihan ini membuat masyarakat tahu tata cara melakukannya, termasuk juga ibu Emma yang sekarang aktif mengurusi jenazah kalau ada yang meninggal di sekitar rumahnya berjenis kelamin perempuan, berikut penuturan beliau:

"Saya sangat senang dengan pelatihan pemulasaran jenazah, karena itu merupakan kewajiban sesama umat islam, saya sudah berani memandikan mayat disekitar sini." 24
Dari jawaban informan, penulis dapat menarik kesimpulan bahwa pelatihan ini dapat meningkatkan prososial masyarakat sebagai contoh ibu Emma sekarang menjadi salah satu pengurus jenazah di sekitar tempat tinggal beliau, meskipun ibu Muntamah dan ibu Amanih masih belum berani tetapi sudah ada keinginan untuk melakukannya di suatu hari, intinya sudah ada bentuk simpati yang ditimbulkan oleh pelatihan tersebut, simpati sendiri merupakan salah satu bagian dari prososial tetapi belum sampai pada tahap empati. Karena mengurus jenazah adalah fardhu kifayah dalam ajaran agama islam, dan hukumnya wajib bagi semua orang islam dewasa yang berada di daerah tersebut untuk mengurus jenazah. Kalau jenazah misalnya tidak di urus akan berdampak pada kehidupan sosial masyarakat, misalnya seperti orang takut, atau bau bangkai yang menyengat, ini merupakan alasan kenapa mengurus jenazah termasuk dalam konteks prososial karena ketika perkara ini ditinggalkan maka dapat berdampak negatif bagi kehidupan orang banyak.

Seandainya saja tidak ada yang bisa mengurus jenazah maka akan timbul permasalahan di tengah-tengah masyarakat yang akan berdampak pada kehidupan sosial masyarakat, karena keteraturan sosial merupakan salah satu komponen yang dapat mengharmoniskan hubungan sesama manusia, kalau keteraturan sosial hilang maka akan berpotensi menghancurkan tatanan sosial yang dijunjung oleh masarakat. 


\section{Pelatihan Khutoba}

Khutbah jum'at adalah perkataan yang terkandung didalamnya mauidzah hasanah serta tausiyah yang berkaitan dengan tuntutan agama yang diucapkan oleh khatib dengan syarat yang telah dirinci menurut syara' dan menjadi rukun dalam pelaksanaan jum'at. Khutbah jum'at merupakan bagian penting dari pelaksanaan shalat jum'at, Karena khutbah menempati 2 rakaat kalau kita melaksanakan shalat dzuhur.

Pelatihan khutbah jum'at termasuk dalam konteks prososial karena khutbah jum'at merupakan serangkaian kewajiban yang harus dilaksanakan dalam menjalankan shalat jum'at. Karena khutbah menempati dua rakaat dari shalat dzuhur, seandainya khutbah jum'at tidak ada maka shalat jum'at tidak akan sah. Sedangkan orang yang membawakan khutbah jum'at adalah khatib, misalnya ketika khatib berhalangan hadir, bisa jadi shalat jum'at di Mesjid tersebut tidak dilaksanakan. Akibatnya, akan berefek bagi masyarakat yang mayoritas muslim dan akan terjadi masalah dalam konteks agama di tengah-tengah masyarakat. Sebab, masyarakat yang mayoritas muslim biasanya patuh terhadap ajaran agama yang dianutnya, jika terjadi di suatu Mesjid misalnya tidak dilaksanakan shalat jum'at karena tidak ada yang bisa menjadi khatib jum'at maka akan terjadi masalah yang sifatnya agama.

Untuk meminimalisir masalah agama tersebut penyuluh mengambil peran yang sangat penting di tengahtengah masyarakat melalui pemberian pelatihan khutbah dan merupakan serangkaian acara kegiatan prososial terhadap masyarakat yang diprogramkan oleh penyuluh agar masyarakat bisa menjadi khatib jika sewaktu-waktu di suatu masjid tidak ada orang yang bisa menjadi khatib jum'at, karena khatib yang diundang berhalangan hadir. Dimulai dengan menyebarkan undanganundangan kepada masyarakat melalui Mesjid-mesjid, kemudian mengumpulkan masyarakat di KUA dan memberikan pelatihan terhadap masyarakat agar memahami syarat-syarat dan rukunrukun khutbah dan teknik penyampaian khutbah"25

Pelatihan khutoba yang di laksanakan di KUA Kebayoran Lama kurang diminati oleh masyarakat karena hanya sedikit saja yang hadir ketika pelatihan ini dilakukan. Pelatihan ini dilaksanakan pada hari selasa tanggal 28 November 2017 dimulai dari pukul 10:00-12:00 siang di Aula lantai 2 Kantor Urusan Agama Kecamatan Kebayoran Lama dengan pemateri Ustadz Komarudin dan di moderatori oleh ibu Zubaedah. Ustadz Komarudin membahas tentang kemulian jum'at, syarat dan rukun khutbah dengan penjelasan penjelasannya berdasarkan rujukan kitab karangan Al Habib Zein bin Ibrahim.

Dari wawancara diatas dan pernyataan dari salah seorang peserta dapat disimpulkan bahwa pelatihan khutbah dapat meningkatkan prososial masyarakat perkotaan dalam bidang agama khususnya, hal itu terbukti dari pengakuan pak Sutarno dan Ustadz Masyhuri yang pernah menjadi khatib jum'at menggantikan khatib yang berhalangan hadir ke Mesjid tempat mereka shalat jum'at, kemudian di 
dukung pernyataan pak mulyono yang bersedia menjadi khatib jum'at jika sewaktu-waktu di tempatnya tidak ada khatib. Karena meskipun pelatihan ini sangat identik dengan agama tetapi cukup sesuai bagi masyarakat Kebayoran Lama yang mayoritas menganut agama islam.

\section{Metode dan Teknik Penyuluhan Masyarakat Organik Kebayoran Lama}

Setelah penulis mengamati di berbagai kegiatan yang dilaksanakan di Kantor Urusan Agama Kebayoran Lama oleh penyuluh setempat, penulis dapat menyimpulkan bahwa metode pendekatan yang digunakan dalam penyuluhan yang bertujuan meningkatkan prososial tidak jauh berbeda dengan metode dan teknik penyuluhan yang lain, baik dari segi penyampaian dan teknik pendekatan audiens hampir semuanya sama. Cuma bedanya karena ini masyarakat organik penyuluh menggunakan teknik yang ekstra untuk mengumpulkan masyarakat organik"26

\section{A. Metode Pendekatan Audiens}

Dalam Observasi yang penulis lakukan dari semua kegiatan yang dilaksanakan oleh penyuluh agama Kebayoran Lama yang bertujuan untuk meningkatkan prososial masyarakat organik Kebayoran Lama, penyuluh agama Kebayoran Lama memiliki teknik tersendiri untuk mendekati audiens, agar masyarakat organik ini tertarik untuk mengikuti kegiatan yang mereka lakukan di KUA, salah satunya dengan menyebarkan undangan ke mesjidmesjid, menganalisis kebutuhan beragama masyarakat kemudian membuat kegiatan dan pelatihan yang sangat dibutuhkan oleh masyarakat yang dikemas menarik agar masyarakat organik ini tertarik untuk mengikuti kegiatan dan meluangkan waktunya yang sibuk untuk mengikuti pelatihan di Kantor Urusan Agama (KUA) Kebayoran Lama. Untuk mendekati audiens penyuluh agama Kebayoran Lama menggunakan dua pendekatan bagi audiens, yaitu :

\section{Pendekatan Individual}

Dalam metode ini, penyuluh berhubungan secara langsung maupun tidak langsung dengan sasarannya secara perorangan. Metode perorangan menurut Kartasaputra (1994), sangat efektif digunakan dalam penyuluhan karena sasaran dapat secara langsung memecahkan masalahnya dengan bimbingan khusus dari penyuluh. Menurut Van Den Ban dan Hawkins (1996), metode pendekatan perorangan pada hakikatnya adalah yang paling efektif dan intensif dibanding metode lainnya. ${ }^{27 P e n d e k a t a n ~ i n d i v i d u ~ a d a l a h ~}$ salah satu metode yang digunakan oleh penyuluh agama Kebayoran Lama untuk menghadapi audiens, pendekatan ini digunakan pada kegiatan konseling karena permasalahan yang diungkapkan oleh masyarakat merupakan permasalahan yang sifatnya privasi. Dalam wawancara penulis dengan penyuluh agama, Ustadz Komar menuturkan : 
"Dalam konseling kita membahas halhal yang privasi, karena biasanya berkaitan dengan pernikahan, masalah dalam keluarga, masalah bertetangga dan juga konsultasi mawaris misalnya."28

\section{Pendekatan Kelompok}

Dalam metode pendekatan kelompok, penyuluh berhubungan dengan sasaran penyuluhan secara kelompok. Metode pendekatan kelompok atau group approach menurut Kartasaputra (1994) cukup efektif, dikarenakan petani atau peternak dan masyarakat dibimbing dan diarahkan secara kelompok untuk melakukan sesuatu kegiatan yang lebih produktif atas dasar kerjasama. Metode dengan pendekatan kelompok lebih menguntungkan karena memungkinkan adanya umpan balik, dan interaksi kelompok yang memberi kesempatan bertukar pengalaman maupun pengaruh terhadap prilaku dan norma para anggotanya. ${ }^{29}$ Dalam observasi penulis pendekatan kelompok merupakan pendekatan yang paling sering digunakan dalam setiap kegiatan penyuluh agama Kebayoran Lama, mulai dari kegiatan di Majlis Ta'lim, Pengajian As Sakinah, Pelatihan Master Of Ceremony, Pelatihan Pemulasaran Jenazah, Pelatihan Khutoba dan Santunan Anak Yatim semuanya menggunakan pendekatan kelompok.

\section{B. Teknik Penyampaian Materi}

Untuk menyampaian materi-materi penyuluhan agar sampai dan tepat guna bagi masyarakat, penulis melihat penyuluh agama Kebayoran Lama menggunakan beberapa metode agar pesan yang di ucapkan oleh penyuluh sampai kepada masyarakat supaya terjadi sebuah perubahan. Penyuluh Agama Kebayoran Lama menggunakan metode langsung dengan tatap muka bersama audiens dan tidak pernah menggunakan metode tidak langsung (tidak dengan tatap muka) atau melalui media seperti Radio dan Televisi.

Berdasarkan informasi melalui wawancara langsung dengan penyuluh di atas penulis mendapati dua metode yang sering dipakai oleh penyuluh agama Kebayoran Lama, tetapi pada pelaksanaannya penulis menemukan satu metode yang tidak disebutkan oleh penyuluh yaitu, metode simulasi. Metode simulasi ini penulis lihat ketika penyuluh mengadakan pelatihan Master of Ceremony dan Pemulasaran Jenazah di KUA Kebayoran Lama, saat itu ada beberapa orang yang disuruh untuk memperaktekkan langsung menjadi pembawa acara, begitu juga dalam pelatihan pemulasaran jenazah penulis juga menyaksikan beberapa orang mempraktekkan langsung bagaimana tata cara mengurus jenazah. Melalui observasi tersebut penulis mendapatkan 3 metode yang digunakan oleh penyuluh agama dalam menyampaikan informasi kepada masyarakat.

\section{a. Ceramah}

Ceramah adalah cara penyajian informasi yang dilakukan pengajar dengan penuturan atau penjelasan lisan secara langsung terhadap pendengar atau sasaran. ${ }^{30}$ Metode ini merupakan metode andalan bagi para penyuluh di KUA Kebayoran Lama karena keterbatasan kemampuan penyuluh dalam mengikuti 
cara-cara penyuluhan yang modern. Dalam metode ceramah ini penyuluh menyampaikan pesan-pesan bagi masyarakat baik yang bertujuan untuk meningkatkan kualitas keagamaan dan kualitas sosial.

Metode ceramah ini sangat efektif bagi masyarakat kebayoran lama, meskipun metode ceramah adalah metode yang biasa tetapi fungsinya masih sangat efektif. Meskipun metode ceramah memiliki banyak kekurangan karena media yang dipakai hanya mikrofon dan soundsistem tetapi keadaan tersebut tidak berpengaruh bagi keberhasilan penyampaian informasi dari penyuluh ke masyarakat.

b. Tanya Jawab

Tanya Jawab adalah metode penyampaian pesan pengajaran dengan cara mengajukan pertanyaan-pertanyaan dan siswa memberikan jawaban atau sebaliknya siswa diberi kesempatan bertanya dan guru menjawab pertanyaanpertanyaan. ${ }^{31}$

Metode tanya jawab ini hampir dilakukan pada setiap metode ceramah yang disampaikan oleh penyuluh agama ketika menyampaikan materi kepada masyarakat, umumnya masyarakat atau peserta yang melakukan tanya jawab karena kurang mengerti dengan penjelasan yang diberikan oleh penyuluh, sebab itu mereka membutuhkan penjelasan kembali dari penyuluh agar mereka dapat memahami apa yang disampaikan oleh penyuluh. Atau masyarakat memang tidak tau sama sekali tentang beberapa hal yang berkaitan dengan apa yang disebutkan oleh penyuluh, akhirnya untuk menghilangkan keraguan, masyarakat berani bertanya kepada penyuluh" 32 Dari observasi yang penulis lakukan pada beberapa kegiatan yang dilakukan oleh penyuluh, terbukti bahwa yang berani bertanya hanya satu atau dua orang saja kepada penyuluh.

\section{c. Simulasi}

Metode simulasi atau rangsangan adalah suatu teknik penyuluhan dengan cara penyuluh merangsang kelompok sasaran dengan pemberian hadiah dukungan dan perlombaan sehingga kelompok sasaran menyadari akan manfaat dari suatu program yang ditawarkan33. Metode simulasi ini digunakan oleh penyuluh ketika mengadakan pelatihan Master of Ceremony dan Pelatihan Pemulasaran Jenazah. Dalam pelatihan tersebut penyuluh menyuruh peserta nuntuk mempraktekkan bagaimana cara menjadi pembawa acara yang baik dan tata cara mengurus jenazah.

Dari observasi penulis, penulis melihat beberapa orang mempraktekkan langsung apa yang disampaikan oleh penyuluh terkait pelatihan Master of Ceremony dan Pemulasaran Jenazah. Pada pelatihan master of ceremony penulis melihatlima orang diperbolehkan mempraktekkan menjadi pembawa acara yang baik dan benar di depan aula KUA, masing-masing peserta diberi waktu lima menit untuk membawakan acara. Untuk tiga peserta yang terbaik menjadi pembawa acara, maka akan mendapat hadiah kado dari penyuluh. Begitu juga dalam pelatihan pemulasaran jenazah meskipun yang mempraktekkan tidak mendapat hadiah, tetapi ada tiga orang 
yang diminta oleh penyuluh untuk maju dan mempraktekkan langsung tata cara memandikan dan mengkafani jenazah.

\section{Alat Penyuluhan}

Untuk mempermudah melakukan penyuluhan, penyuluh membutuhkan alat bantu yang dapat menunjang keberhasilan penyuluhan yang disebut dengan alat penyuluhan. Alat penyuluhan dapat memberikan pengaruh besar untuk terjadinya sebuah perubahan. Berdasarkan penuturan dari penyuluh agama Kebayoran Lama terkait media yang digunakan dalam penyuluhan, mereka mengatakan :

"Kalau alatnya hampir tidak pernah infokus, hanya mikropon aja, papan tulis juga spidol.34 Penyuluh kedua menyebutkan hanya micropon dan soudsystem. 35 Penyuluh ketiga mengatakan kadang kita juga make infokus tetapi jarang, seringnya micropon doang ama kitab. ${ }^{36}$

Berdasarkan wawancara penulis di atas dengan tiga informan dari penyuluh, penulis dapat mengidentifikasi bahwa alat pendukung dalam proses penyuluhan yang dilakukan oleh penyuluh agama Kebayoran Lama terhadap masyarakat menggunakan media mikropon yang berfungsi sebagai penyaring suara, soundsistem berfungsi sebagai pengeras suara, spidol sebagai alat tulis di papan tulis, kitab sebagai panduan dan rujukan ketika memberikan materi, sementara penggunaan infokus jarang digunakan karena hanya beberapa orang saja diantara penyuluh yang bisa mengoperasikan komputer dengan baik.
Dalam catatan lapangan penulis, penulis mendapat dua tambahan media yang digunakan oleh penyuluh agama Kebayoran Lama dalam proses penyuluhan yaitu, makalah dan alat peraga. Makalah diberikan penyuluh kepada peserta kegiatan pelatihan Master Of Ceremony dan Pelatihan Khutoba', makalah ini berisi tentang materi yang akan disampaikan oleh pemateri terhadap peserta. Alat peraga diberikan penyuluh untuk memudahkan proses simulasi seperti menggunakan guling sebagai peraga bagi mayat ketika pelatihan pemulasaran jenazah.

\section{Peran Penyuluh Agama dalam} Meningkatkan Perilaku Prososial

\section{Masyarakat Organik Kebayoran}

\section{Lama}

Dalam penelitian penulis tentang peran penyuluh agama dalam meningkatkan prososial, terdapat beberapa peran yang ditemui oleh penulis dalam pelaksanaan penyuluhan bagi masyarakat organik Kebayoran Lama, untuk bisa mengetahui peranperan tersebut penulis telah mengamati banyak kegiatan yang dilakukan oleh penyuluh agama Kebayoran Lama diantara peran penyuluh yang dapat penulis temukan adalah sebagai berikut :

a. Peran Informatif dan Edukatif

Peran informatif dan edukatif atau pemberi terang dengan informasi dan wawasan bagi masyarakat, hal ini sesuai dengan asal kata penyuluh yang berarti suluh atau obor yang berarti pemberi terang. Penyuluh agama Kebayoran Lama selalu berusaha memberikan informasi bagi masyarakat Kebayoran Lama baik 
informasi dalam sektor mensejahterakan masyarakat seperti informasi produk makanan halal dalam islam, bahaya narkoba, dan sebagainya. Penyuluh juga memberikan edukasi dalam bidang ilmu pengetahuan yang sifatnya berhubungan dengan kehidupan beragama masyarakat. Sebagai contoh nyata bahwa penyuluh agama Kebayoran Lama memberikan informasi dan edukasi bagi masyarakat organik Kebayoran Lama, mereka selalu aktif dalam kegiatan-kegiatan keagamaan di tengah-tengah masyarakat melalui kegiatan pengajian-pengajian di Majlis Ta'lim, penyuluh berusaha memberikan informasi-informasi dan edukasi yang belum diketahui oleh masyarakat agar masyarakat semakin terpelajar dan berusaha mengamalkan yang sudah diketahui dalam tindakan seharihari,baik yang berkaitan dengan Fiqih, Tauhid, Akhlak, dan mempelajari Bahasa Arab agar masyarakat keluar dari kebodohan beragama.

\section{b. Peran Pendamping}

Peran pendampingan sangat dibutuhkan oleh masyarakat Kebayoran Lama dalam penanggulangan masalahmasalah yang terjadi di tengah-tengah masyarakat organik baik permasalahan agama, juga permasalahan sosial bermasyarakat yang dimotori oleh penyuluh agama setempat. Oleh karena itu, penyuluh agama Kebayoran Lama berusaha mengatasi masalah-masalah yang terjadi di tengah-tengah masyarakat seperti masalah perceraian dengan mengadakan konseling, kondisi pendidikan agama anak-anak dengan menghidupkan kembali TPQ di Mesjidmesjid, kondisi pendidikan agama bagi orang tua dan remaja dengan mengadakan pengajian di Majlis-majlis Ta'lim, serta masalah lain yang terjadi dalam kehidupan bermasyarakat. sebagai kerja nyata bahwa penyuluh ikut mendampingi masyarakat untuk menangani permasalahan masyarakat penyuluh membuka konsultasi setiap hari bagi masyarakat Kebayoran Lama untuk mengadukan permasalahan yang mereka hadapi dan mencari jalan keluar untuk memecahkan masalah tersebut dengan konsultasi kepada penyuluh.

\section{c. Peran Pembina}

Peran pembina yang diberikan oleh penyuluh agama bertujuan untuk meningkatkan keinginan masyarakat untuk tergerak melakukan suatu perubahan, dengan adanya proses pelatihan-pelatihan yang dipelopori oleh penyuluh. Penyuluh berharap masyarakat organik Kebayoran Lama bersedia dan mampu melakukan suatu kegiatan positif di masyarakat setelah diberikan pengetahuan dan pelatihan oleh penyuluh. Penyuluh agama Kebayoran Lama memiliki beberapa kegiatan pelatihan yang dirancang untuk kemaslahatan bersama di kalangan masyarakat setempat, meskipun yang hadir tidak banyak hanya perwakilan saja dari masing-masing kelurahan, tetapi cukup menjadi bukti bahwa penyuluh agama Kebayoran Lama memainkan perannya dalam membina masyarakat dengan memberikan pelatihan-pelatihan yang di adakan di Kantor Urusan Agama Kecamatan Kebayoran Lama. Diantaranya pelatihan Pemulasaran (mengurus) Jenazah, pelatihan Master Of Ceremony dan pelatihan Khutoba'. 
d. Peran Agen Perubahan dan Fasilitator

Agen perubahan adalah salah satu fungsi dari penyuluh agama, hal itu juga yang dilakukan oleh penyuluh agama Kebayoran Lama, penyuluh agama Kebayoran Lama bersama dengan KUA Kebayoran Lama menggagas sebuah kegiatan keagamaan yang melibatkan segenap kantor pemerintahan di wilayah Kebayoran Lama, dimulai dari pegawai kecamatan, kelurahan, pegawai di di kepolisian sekitar, koramil dan juga masyarakat mengadakan sebuah pengajian bulanan yang diadakan di instansi pemerintahan seperti kantor kecamatan, kantor kelurahan, kantor polsek, kantor koramil dan KUA yang berganti-gantian setiap bulannya. Kegiatan pengajian yang dinamai dengan Pengajian Umaro ini cukup memberikan pengaruh bagi seluruh instansi pemerintahan di Kebayoran Lama terlebih masyarakat, karena pada saat pengajian masyarakat dan pemerintah duduk bersama mengikuti pengajian, bersama-sama mendengarkan ceramah yang diberikan oleh penceramah yang di undang penyuluh. Selain pengajian, kegiatan ini juga berfungsi sebagai ajang pengaduan masyarakat bagi pemerintah serta mendekatkan pemerintah dengan masyarakat Kebayoran Lama.

Analisis Peran Penyuluh Agama dalam Meningkatkan Perilaku Prososial Masyarakat Organik Kebayoran Lama

Dalam penelitian ini, peran penyuluh agama dalam meningkatkan prososial masyarakat organik di Kebayoran Lama
Jakarta Selatan adalah dengan memberikan kegiatan yang bertujuan untuk meningkatkan prososial masyarakat perkotaan melalui kegiatan pengajian di Majlis Ta'lim yang berkaitan dengan materi akhlak, karena akhlak sangat erat kaitannya dengan prilaku menolong, akhlak mencakup hubungan manusia dengan Allah dan manusia. Peran penyuluh lainnya dengan memberikan pelatihan pemulasaran jenazah dan pelatihan khutoba, keduanya merupakan kegiatan yang bertujuan meningkatkan prososial sebab keduanya erat kaitannya dengan kehidupan orang banyak dan sangat dibutuhkan oleh masyarakat Kebayoran Lama yang mayoritas menganut agama islam.

Metode yang digunakan oleh penyuluh agama dalam meningkatkan prososial tidak beda jauh dengan metode penyuluhan pada umumnya yakni dengan pendekatan individu dan kelompok dengan teknik penyampaian ceramah, tanya jawab dan simulasi.

Hasil observasi dan wawancara langsung dilapangan dengan beberapa informan menunjukkan bahwa beberapa bentuk kegiatan yang diselenggarakan oleh penyuluh setempat dapat meningkatkan prososial masyarakat. Kegiatan pengajian di Majlis Ta'lim misalnya, khususnya tema-tema yang berkaitan dengan berbuat baik terhadap sesama manusia dan berlomba-lomba dalam kebaikan dapat memberikan stimulus bagi masyarakat untuk senantiasa membantu orang lain, terlihat ada perubahan yang sebelumnya jarang membantu menjadi semakin sering membantu seperti yang dialami oleh umi 
Muntamah, kalau misalnya tidak bisa membantu dengan hal yang besar beliau berusaha cukup dengan memberi makanan ke tetangga, dan mengajak orang dalam kebaikan. Begitu juga yang terjadi dengan ibu Amanih setelah mengikuti pengajian dia merasa semakin ingin berbuat banyak halbagi masyarakat, sebagai contoh dia membuat grup di WhatsApp yang bertujuan untuk mengajak orang sekitar rumahnya untuk selalu meningkatkan ibadah kepada Allah, beliau mengkontrol terus setiap saat agar masyarakat terbantu berkompetisi dalam kebaikan.

Kegiatan pelatihan Pemulasaran (mengurus) Jenazah dan Khutoba' sangat membantu bagi masyarakat Kebayoran Lama menurut penuturan beberapa informan, sebagai contoh ibu Emma sebelum mengikuti pelatihan di KUA beliau belum berani untuk mengurusi jenazah karena masih banyak hal-hal yang belum diketahui terkait tata caranya, setelah mengikuti pelatihan yang diberikan oleh penyuluh beliau sekarang aktif mengurus jenazah disekitar tempat tinggalnya selain karna memang kewajiban tetapi mengurus jenazah merupakan salah satu tindakan yang bernilai prososial. Pelatihan Khutoba' juga sangat bermanfaat bagi masyarakat tutur ustadz Masyhuri, beliau pernah menjadi khotib jum'at di mesjid sekitar stasiun kebayoran lama karena jamaah yang hadir tidak ada yang mampu menjadi khotib. Ustadz Masyhuri semakin percaya diri menjadi khotib setelah mengikuti pelatihan di KUA.

\section{Penutup}

Dari hasil penelitian skripsi penulis yang berjudul Peran Penyuluh Agama dalam Meningkatkan Perilaku Prososial Masyarakat Organik (Masyarakat Perkotaan) Kebayoran Lama Jakarta Selatan yang berpusat di Kantor Urusan Agama Kebayoran Lama dapat ditarik kesimpulan sebagai berikut:

Dalam pelaksanaan kegiatan yang bertujuan meningkatkan prososial masyarakat organik Kebayoran Lama dilakukan oleh penyuluh agama setempat dan juga ustadz-ustadz dalam masyarakat yang berada dibawah kontrol penyuluh agama fungsional Kebayoran Lama. Upaya yang dilakukan oleh penyuluh agama setempat dengan mengumpulkan masyarakat organik Kebayoran Lama yang terdiri dari enam kelurahan untuk diberikan pelatihan dan kajian yang berisi doktirn-doktrin keagamaan yang bertujuan untuk menambah wawasan keislaman masyarakat organik Kebayoran Lama agar tercipta masyarakat yang agamis. Sebab, semakin sering masyarakat organik berkumpul dalam kegiatan keagamaan akan menimbulkan terjadinya interaksi yang banyak dalam masyarakat organik, jika terjadi interaksi yang intensitasnya tinggi dalam masyarakat organik maka hubungan masyarakat organik akan semakin dekat dengan masyarakat organik lainnya. Ketika hubungan diantara masyarakat organik sudah dekat, maka akan terjalin sebuah hubungan yang harmonis, toleran, damai, suka menolong, dan sebagainya di tengah-tengah kehidupan masyarakat organik. Hasilnya adalah akan timbul simpul-simpul di tengah- 
tengah masyarakat organik yang gemar tolong-menolong sesuai dengan kultur masyarakat Indonesia. Kemudian masyarakat organik akan terhindar dari sifat apatis dan antisosial yang dapat merusak keharmonisan kehidupan bermasyarakat di perkotaan. Diantara kegiatan yang berisi doktrin-doktrin keagamaan yang diberikan oleh penyuluh agama bagi masyarakat organik adalahkegiatan pengajian Majlis Ta'lim, pengajian As-sakinah, pelatihan Pemulasaran (mengurus) Jenazah, pelatihan Master Of Ceremony, pelatihan Khutoba, Konseling, dan Ngaji Kitab Kuning. Tempat pelaksanan kegiatan kalau Majlis Ta'lim dilaksanakan di Masjid, Musholla, dan Instansi pemerintahan. Sementara untuk kegiatan selain Majlis Ta'lim semuanya dilaksanakan di Aula lantai 2 Kantor Urusan Agama Kecamatan Kebayoran Lama.

Metode dan teknik yang digunakan oleh penyuluh agama dalam meningkatkan prososial masyarakat perkotaan di Kebayoran Lama adalah dengan menganalisa kebutuhan yang paling urgent dalam kehidupan beragama di tengah-tengah masyarakat. Karena labelnya penyuluh agama, maka pesan yang disampaikan juga berisi agama yang di anut oleh penyuluhnya yaitu Islam. Metode yang digunakan dalam kegiatan penyuluhan yang bertujuan meningkatkan prososial masyarakat organik Kebayoran Lama adalah ceramah, tanya jawab dan simulasi. Sementara untuk alat yang dipakai adalah microfon, soundsistem, infokus, spidol, dan buku atau kitab. Cara mendekati audiens penyuluhan, penyuluh agama setempat menggunakan pendekatan langsung dengan kelompok dan individu. Selanjutnya, untuk materi yang digunakan dalam penyuluhan adalah ahklak sebagai materi pokok, untuk materi yang penting adalah Fiqih, Tauhid, dan Bahasa Arab, dan materi penunjang adalah materi selain yang diatas. Sementara teknik yang dipakai oleh penyuluh agama untuk mengumpulkan masyarakat organik yang sibuk dan memiliki kegiatan beragam barang tentu sangat sulit untuk dipadukan, penyuluh memilih teknik dengan menyebarkan undanganundangan ke Mesjid-mesjid yang berisi kegiatan-kegiatan yang akan dilaksanakan di KUA, sekaligus mensosialisasikan kegiatan di KUA yang dikemas semenarik mungkin supaya masyarakat tertarik untuk menghadiri kegiatan salah satunya dengan mengadakan pengajian dan pelatihan yang sangat urgent dalam kehidupan masyarakat organik. Yaitu, pengajian rutin di Majlis Ta'lim, pelatihan Pemulasaran Jenazah dan Pelatihan Khutoba'. Penyuluh memilih demikian, karena dalam kehidupan masyarakat organik yang taat beragama tidak terlepas dari praktek ibadah, maka pengajian dibutuhkan untuk mengajari masyarakat tentang tata cara beribadah yang benar. Masyarakat yang beragama islam juga tidak asing praktek ibadah shalat jum'at dan mengurus jenazah, sebab kalau dua kegiatan ibadah itu tidak dilaksanakan akan berakibat dosa bagi seluruh masyarakat dan akan berimbas pada kehidupan kelak di akhirat. 
Peran penyuluh agama dalam meningkatkan perilaku prososial masyarakat organik Kebayoran Lama adalah sebagai berikut: Penyebar informasi dan memberikan edukasi berupa informasi dan pengetahuan pengetahuan yang sangat dibutuhkan oleh masyarakat dalam kehidupan beragama, bernegara dan bermasyarakat; Pendamping masyarakat, Penyuluh mengisi waktu untuk mendampingi masyarakat dalam mengatasi masalahmasalah dalam kehidupannya, baik yang sifatnya khusus seperti permasalahan rumah tangga, atau yang umum seperti permasalahan yang dirasakan orang banyak; Pembina Masyarakat, penyuluh agama Kebayoran Lama memberikan kegiatan pelatihan yang melibatkan masyarakat setempat agar masyarakat bisa mempraktekkan langsung apa yang didapat dari pelatihan yang diberikan oleh penyuluh agama Kebayoran Lama.

(a) Agen perubahan di tengah tengah masyarakat organik, karena penyuluh agama Kebayoran Lama menggagas sebuah inovasi pengajian yang melibatkan masyarakat dan pemerintah yang sangat diterima oleh masyarakat dari kalangan elit dan masyarakat sipil.

(b) Sebagai fasilitator, karena penyuluh memberikan fasilitas untuk masyarakat agar dapat bertemu dan berdiskusi dengan pemerintah setempat dan mengadukan keluh kesah masyarakat kepada pemerintah setempat tanpa perantara, agar tercipta pemerintahan yang baik yang disukai oleh masyarakat.
Catatan kaki:

1 Cucu Nurhayati, Sosiologi perkotaan, (Ciputat: Uin Jakarta Press, 2013), h. 8.

2 Khaldun, Muqaddimah Ibn Khaldun (terj), (Jakarta: Pustaka Firdaus, 2011), h. 429.

3 Bintarto, Interaksi Desa-Kota, (Jakarta: Ghalia Indonesia, 1983),h. 76.

4 Departemen Sosial RI, Buku Pedoman Umum Pelayanan dan Rehabilitasi Tuna Susila, (Jakarta: Salemba), h. 1-2.

5 Kementerian agama, Buku panduan Pelaksanaan Tugas Penyuluh Agama, (Jakarta: Kemenag, 2003), h. 13.

6 Harun Nasution, Islam Ditinjau dari Berbagai Aspeknya, (Jakarta: Universitas Indonesia Press. 1985), h. 9-10.

7 Hendropuspito, Sosiologi Agama, (Yogyakarta: PT. Kanisius, 2000), h. 34.

8 Dadang Kahmad, Sosiologi Agama,(Bandung: PT Rosdakarya, 2000), h. 13 .

$9 \quad$ Kementerian agama, Buku panduan Pelaksanaan Tugas Penyuluh Agama, (Jakarta: Kemenag, 2003), h. 10.

10 Sarlito W. Sarwono dan Eko A. Meinaro, Psikologi Sosial, (Jakarta: Salemba Humanika, 2011), h. 141.

${ }^{11}$ Jenny Mercer dan Debby Clayton, Psikologi Sosial, (Jakarta: Erlangga, 2012), h. 121.

${ }_{12}$ Sarlito W. Sarwono dan Eko A. Meinaro, Psikologi Sosial, (Jakarta: Salemba Humanika, 2011), h. 123.

${ }^{13}$ Tri Dayaksini dan Hudaniah, Psikologi Sosial (Malang: UMM, 2003), h. 177.

${ }^{14}$ Hadi Sabari Yunus, Manajemen Kota Perspektif Sosial,(Yogyakarta: Pustaka Pelajar, 2011), h. 39.

15Fitri Ramadhani Harahap, Dampak Urbanisasi bagai Perkembangan Kota di Indonesia. Jurnal Society, Vol. 1, No. 1, Juni 2013.

${ }^{16}$ Hadi Sabari Yunus, Manajemen Kota Perspektif Sosial,(Yogyakarta: Pustaka Pelajar, 2011), h. 41.

${ }^{17} \mathrm{Cucu} \quad$ Nurhayati, Sosiologi perkotaan,(Ciputat: Uin Jakarta Press, 2013), h. 42.

${ }^{18}$ Dikutip dari arsip Kecamatan Kebayoran Lama periode 2016 pada 29 September 2017.

19Wawancara Pribadi dengan ustadzah Siti Pahriyah di KUA Kebayoran Lama pada 30 September 2017 pukul 10:00-10:20 WIB.

${ }^{20}$ Wawancara Pribadi dengan ustadzah Siti Pahriyah di KUA Kebayoran Lama pada 
30 September 2017 pukul 10:00-10:20 WIB.

${ }^{21}$ Wawancara pribadi dengan Ustadz Komarudin, KUA Kebayoran Lama, 11 September 2017 Pukul 10: 00-10:30 WIB.

22Jalaluddin, Psikologi Agama (Jakarta: Raja Grafindo Persada, 2005), h. 264.

23Wawancara Pribadi dengan Ustadz Masyhuri Husin di Kantor Takaful pada 29 Desember 2017 pukul 10:12-10:30 WIB. 24Wawancara Pribadi dengan Ibu Emma di Rumah beliau di Grogol Selatan Kebayoran Lama pada o9 Januari 2018 pukul 11:30-12:04 WIB.

25Pernyataan Ustadz Komarudin ketika menjadi pemateri pelatihan khutoba, di KUA Kebayoran Lama 28 November 2017 Pukul 10 : 00 -12 :00.

${ }^{26}$ Wawancara Pribadi dengan Ustadz Komarudin di KUA Kebayoran Lama pada 21 November 2017 pukul 10:00-10:19.

${ }^{27}$ Setiana, Lucie, Teknik Penyuluhan dan Pemberdayaan Masyarakat, (Bogor: Ghalia Indonesia, 2005) h. 49.

${ }^{28}$ Wawancara Pribadi dengan Ustadz Komar di KUA Kebayoran Lama, pada 18 Desember 2017 pukul 12:00-12:30 WIB

29 Setiana, Lucie, Teknik Penyuluhan dan Pemberdayaan Masyarakat, (Bogor: Ghalia Indonesia, 2005) h. 50.

${ }^{30}$ Eliza Herijulianti Dkk, Pendidikan Kesehatan Gigi,(Jakarta: Buku Kedokteran EGC, 2001), h. 67.

${ }^{3}$ Basyiruddin Usman, Metodologi Pembelajaran Agama Islam, (Jakarta Selatan: Ciputat Press, 2002), h. 43.

${ }^{32}$ Wawancara Pribadi dengan Ustadz Komarudin di KUA Kebayoran Lama, pada 18 Desember 2017 pukul 12:00 -12:30 WIB.

33Eliza Herijulianti Dkk, Pendidikan Kesehatan Gigi,(Jakarta: Buku Kedokteran EGC, 2001), h. 65.

34Wawancara Pribadi dengan Ustadz Komarudin di KUA Kebayoran Lama pada 21 November 2017 pukul 10:00-10:19 WIB.

35Wawancara Pribadi dengan Ustadzah Mumun Fauziah di KUA Kebayoran Lama pada 4 Desember 2017 pukul 11:00-11:12 WIB.

${ }^{36}$ Wawancara Pribadi dengan Ustadzah Siti Pahriyah di KUA Kebayoran Lama, pada o6 Desember 2017 pukul 13:10 - 13:25 WIB.

\section{DAFTAR PUSTAKA}

Adiyla. 2010. Website Notaris Sebagai Media Penyuluhan Hukum Sehubungan dengan Pembuatan Akta Notaris. Depok: Fakultas Hukum Universitas Indonesia.

Agus, Bustanuddin. 2010. Agama dan Fenomena Sosial: Buku Ajar Sosiologi Agama. Jakarta: Universitas Indonesia.

Ahmadi, Abu. 1991. Psikologi Sosial. Jakarta: Rineka Cipta.

Arifin, Isep Zainal. 2009. Bimbingan Penyuluhan Islam (Pengembangan Dakwah Melalui Psikoterapi Islam. Jakarta: Rajawali.

A., Hallen. 2013. Bimbingan dan Konseling. Jakarta: Ciputat Pers.

Bandono, Agus. 2002. Agama Sebagai Fenomena Sosiologi. Depok: Fakultas Pengetahuan Budaya Universitas Indonesia.

Baron A., Robert dan Donn Byrne. 1983. Psikologi Sosial. Jakarta: Erlangga.

Bintarto. Interaksi Desa-Kota. Jakarta: Ghalia Indonesia.

Darajat, Zakiah. 1995. Metodik Khusus Pengajaran AgamaIslam.Jakarta: Bumi Aksara.

Dayaksini, Tri dan Hadaniah. 2003. Psikologi Sosial. Malang: UMM

Departemen Sosial RI, Buku Pedoman Umum Pelayanan dan Rehabilitasi Tuna Susila. Jakarta: Salemba.

Depdiknas. 2002. Kamus Besar Bahasa Indonesia. Jakarta: Balai Pustaka.

Echole, Jhon M., dan Hasan Sadily. 1995. Kamus Inggris Indonesia. Jakarta: PT Gramedia.

Edwin, Iren Datmeswari, Sistem dan Dinamika Keluarga dalam Pembentukan Prilaku Prososial pada 
Anak. Psikodinamika, Vol. 1, No. 2 (April 2002): h. 2.

Emzir. 2008. Metodologi Penelitian Pendidikan Kuantitatif \& Kualitatif. Jakarta: PT RajaGrafindo Persada.

Fadli, Zulkarnain. 2013. Peran Penyuluh Agama dalam Membina Akhlak Jamaah Islamic Cultural Center (JCC) Pejaten Barat Jakarta Selatan, Ciputat: UIN Syarif Hidayatullah.

Hasanah, Siti Uswatun. 2011. Memoar Dakwah : Semangat Dakwah Antara Da’i yang Terlahir Muslim dengan Då Mualaf.Ciputat: Pusat Pengembangan Pendidikan Agama dan Sosial.

Herijulianti, Eliza., Dkk. 2001. Pendidikan Kesehatan Gigi. Jakarta: Buku Kedokteran EGC.

Ikbal, Muhammad. 2010. Potensi Peran Tokoh Agama dalam Pencegahan Penyakit Malaria di Kabupaten Bima Provinsi Nusa Tenggara Barat Tahun 201O. Depok: Fakultas Kesehatan Universitas Indonesia.

J. Moleong, Lexi. 1993. Metode Penelitian Kulalitatif. Bandung: PT. Remaja Rosdakarya.

Kahmad, Dadang. 200o. Sosiologi Agama. Bandung: PT Rosdakarya.

Kartono, Drajat Tri. 2013. Sosiologi Kota. Jakarta: Universitas Terbuka.

Kemenag.2003. Buku Panduan Pelaksanaan Tugas Penyuluh Agama. Jakarta: Kemenag.

Khaldun, Ibnu. 2011. Muqaddimah Ibn Khaldun (terj). Jakarta: Pustaka Firdaus.

Lucie, Setiana. 2005. Teknik Penyuluhan dan Pemberdayaan Masyarakat. Bogor: Ghalia Indonesia.
Mercer, Jenny. dan Debby Clayton. 2012. Psikologi Sosial. Jakarta: Erlangga.

Mubayyinah.2016. Strukturasi Dalam Komunikasi Organisasi Bimbingan dan Penyluuhan Agama Islam di Kementerian Agama Jakarta Barat. Ciputat: Cinta Buku Media.

Muzaijin, Masdar, dan Suaedy Soleh. Penyuluh Agama Ujung Tombak Pengembangan Masyarakat dan Kompetensi yang dibutuhkannya. Jurnal Tenaga Tekhnis Keagamaan, 1 November 2005. Vol. 269.

Narwoko, Dwi J. Dan Bagong Suyatno. 2007. Sosiologi : Teks Pengantar dan Terapan. Jakarta: Kencana.

Nasution, Harun. 1985. Islam Ditinjau dari Berbagai Aspeknya. Jakarta: Universitas Indonesia.

Nasution, Zulkarimein. 1990. Prinsipprinsip Komunikasi untuk Penyuluhan. Jakarta: Fakultas Ekonomi Universitas Indonesia.

Nurhayati, Cucu. 2013. Sosiologi perkotaan. Ciputat: Uin Jakarta Press.

Partanto, Pios, A. 1995. Kamus Ilmiah Populer. Surabaya: Arkola.

Patimah, Wiwit. 2012. Peran Penyuluh Agama dalam Pembinaan Akhlak Wanita Tuna Susila di Panti Sosial Bina Karya Wanita Harapan Mulia Jakarta Barat. Ciputat: UIN Syarif Hidayatullah.

Poerwadarminta, W.J.S. 1976. Kamus Ilmiah Modern. Jakarta: Jembatan.

Rakhmat, Jalaludin. 2005. Psikologi Agama. Jakarta: RajaGrafindo Persada.

Rasyid, Abdul. 2014. Pembinaan Keagamaan dalam Mengembangkan Nilai-nilai Kecerdasan Spritual Anak jalanan di Sanggar Kreatif Anak 
Bangsa (SKAB) Ciputat TangSel. Walgito, Bimo. 1986. Bimbingan dan Ciputat: UIN Syarif Hidayatullah.

Rudyansjah, Tony. 2015. Emile Penyuluhan di Sekolah. Yogyakarta: Durkheim:Pemikiran Utama dan Yunus, Sabari Hadi. 2011. Manajemen percabangannya ke Radcliffe-Brown, Fortes, Levi-Strauss, Turner, dan Holbraad. Palmerah Selatan: Kompas.

Sarwono, Sarlito. 1984. Teori-teori Psikologi Sosial. Jakarta: Rajawali.

Sarwono, Sarlito., dan Eko A. Meinaro. 2011. Psikologi Sosial. Jakarta: Salemba Humanika.

Singarimbun, Masri. dan Sofyan Efendi. 1983. Metodologi Penelitian Survey. Jakarta: LP3ES.

Soetomo. 1995. Masalah Sosial dan Pembangunan. Jakarta: PT Dunia Pustaka Jaya.

Suharto, Edi. 2005. Membangun Masyarakat Memberdayakan Rakyat. Bandung: PT Refika Aditama.

Sulistyaningsih, 2011. Metodologi Penelitian Kebidanan Kualitatif Kuantitatif. Yogyakarta: Graha Ilmu.

Sunarto, Kamanto. 2002. Pengantar Sosiologi. Jakarta: Fakultas Ekonomi Universitas Indonesia.

Tim Penulis Fakultas Psikologi UI. 2011. Psikologi Sosial. Jakarta: Salemba Humanika.

Towansiba, David. 2006. Peran Petugas Penyuluh Lapangan (PPL) dalam Program Pembangunan Perkebunan Kelapa Sawit Pola PIR BUN 20012008 (Suatu studi di Distrik Praki Kabupaten Manokwari Provinsi Irian Jaya Barat. Depok: Fakultas Ilmu Sosial dan Politik Universitas Indonesia.

Usman, Basyiruddin. 2002. Metodologi Pembelajaran Agama Islam. Jakarta Selatan: Ciputat Press. 